\title{
The effects of folic acid supplementation during pregnancy in the rat
}

\author{
BY B. L. G. MORGAN AND M. WINICK \\ Institute of Human Nutrition, Columbia University, College of Physicians and Surgeons, \\ 630 West I68th Street, New York, New York 10032, USA
}

(Received 3 January 1978 - Accepted I5 June 1978)

I. Twenty-four Sprague-Dawley female rats were randomly assigned to three groups (groups A, B, C). Group A was given a folic acid-free diet and groups B and C received $0.0018 \mathrm{~g}$ folic acid $/ \mathrm{kg}$ diet. Rats in $\mathrm{g}$ oup $\mathrm{C}$ were also given a supplement of $\mathrm{I} \mathrm{mg}$ folic acid/d by intraperitoneal injection.

2. After $14 \mathrm{~d}$ of feeding the rats were mated. The diets were continued throughout gestation. On day $2 \mathrm{I}$, of gestation the dams were killed and their livers and products of conception assayed for RNA, DNA, protein and tetrahydrofolate dehydrogenase (5,6,7,8-tetrahydrofolate dehydrogenase; $E C$ I . 5 . I . 3) activity.

3. The foetuses, placentas and livers from supplemented rats (group $C$ ) were significantly larger than those from groups A and B and had a higher content of RNA, DNA and protein. Those tissues from group A dams were smaller than those from the other groups and had a correspondingly reduced nucleic acid and protein content.

4. The activity of tetrahydrofolate dehydrogenase, the first and rate-limiting enzyme in the metabolism of folate, was increased in the folate supplemented rats (group C) and reduced in the rats given a folic acid-free diet (group A). These changes in enzyme activity could explain the differences in nucleic acid biosynthesis and growth shown by the different groups.

There is much evidence to support the view that maternal diet during pregnancy influences the birth weight and composition of the offspring (Nelson \& Evans, 1953; Winick, 1968; Zeman \& Stanbrough, 1969; Naismith \& Morgan, 1976; Morgan \& Naismith, 1977). Foetal stores of folic acid in infants born to mothers with inadequate folic acid intakes are low (Iyengar \& Apte, 1972). Furthermore, the administration of folic acid supplements to pregnant women in certain low socio-economic groups during the last trimester of pregnancy may improve the birth weights of the resulting offspring (Iyengar \& Rajalakshmi, 1975). These authors suggest that this effect is mediated by an increase in placental size and function. However, there could be an alternative explanation.

A deficiency of folic acid may lead to a deficiency of all or just one of the coenzymic forms of the vitamin that are involved as cofactors in the biosynthetic pathway of purines and pyrimidines. Therefore, this could lead to a direct impairment to growth of both the foetus and the placenta. In order to examine the effects of maternal folic acid intake during pregnancy on foetal growth and explore the underlying mechanisms, the effects of maternal supplementation of folic acid on the composition of the products of conception as well as on the activity of tetrahydrofolate dehydrogenase $(5,6,7,8$-tetrahydrofolate dehydrogenase; $E C$ I.5.I.3) in these tissues was measured. This enzyme is the first and rate-limiting enzyme in the metabolism of folate, reducing the latter to tetrahydrofolate, which can then accept $\mathrm{C}_{1}$ moieties from various sources to produce metabolically-active forms of the vitamin.

\section{EXPERIMENTAL METHODS}

Twenty-four rats of the Sprague-Dawley strain weighing approximately $250 \mathrm{~g}$ were selected as triplets of littermates on the basis of similarity in body-weights. The members of each triplet were randomly assigned to three groups and housed individually in cages with wire grids as bases. Groups B and $\mathrm{C}$ were fed on a complete diet containing $200 \mathrm{~g}$ casein and 
Table I. Composition $(\mathrm{g} / \mathrm{kg})$ of experimental diets for groups $B$ and $C$

$\begin{array}{lr}\text { Constituent } & \\ \text { Casein (vitamin free) } & 200 \cdot 0 \\ \text { Corn starch } & 587.5 \\ \text { Peanut oil } & 150.0 \\ \text { DL-Methionine } & 2.5 \\ \text { Salt mix* } & 40.0 \\ \text { Vitamin mix } \dagger & 20.0\end{array}$

* Salt mix formulated after Bernhart \& Tomarelli (I966).

$\dagger$ Composition of vitamin $\mathrm{mix} / \mathrm{kg}$ diet: retinol $(4.0 \mathrm{mg})$, cholecalciferol $(3.0 \mu \mathrm{g})$, phylloquinone (I.0 mg), tocopheryl acetate (II $.75 \mathrm{mg}$ ), thiamin hydrochloride (10.0 mg), nicotinic acid (40.0 $\mathrm{mg})$, riboflavin (10.0 mg), calcium pantothenate $(40.0 \mathrm{mg}$ ), folic acid $(1.8 \mathrm{mg})$, biotin ( $1.0 \mathrm{mg})$, pyridoxine hydrochloride $(10.0 \mathrm{mg})$, vitamin $\mathbf{B}_{12}(5.0 \mathrm{mg})$, choline $(1.0 \mathrm{mg})$, ascorbic acid $(75.0 \mathrm{mg})$ and cellulose carrier (I7623.2 mg).

$0.0018 \mathrm{~g}$ folic acid $/ \mathrm{kg}$ (Table $\mathrm{r}$ ). Group A was fed on a diet identical in composition to that for groups B and C except that folic acid was omitted. All members of the same litter-mate triplet were given the same amount of food during the course of pregnancy (i.e. $370 \mathrm{~g}$ ) adjusted according to the appetite of the rat which ate the least. The test diets were mixed to a thin paste with water and given twice daily, at II.00 and 18.00 hours.

After $14 \mathrm{~d}$ on their respective diets the rats were mated, pregnancy being dated from the appearance of a mating plug. The dams were pair fed on the same diets as before throughout pregnancy. Groups $A$ and $B$ received in addition a daily intraperitoneal injection of $I \mathrm{ml}$ saline ( 9 g sodium chloride/1) throughout pregnancy. Group $\mathrm{C}$ was given an injection of I $\mathrm{ml}$ saline containing I $\mathrm{mg}$ folic acid daily throughout gestation.

The animals were killed on the morning of the 2 Ist day of gestation. Livers, placentas and foetuses were dissected out and analysed for protein, RNA and DNA. The livers and foetuses were also assayed for tetrahydrofolate dehydrogenase activity.

Protein was estimated by the procedure of Lowry, Rosebrough, Farr \& Randall (195I). RNA was extracted as recommended by Munro \& Fleck (I966) and quantitatively determined from the extinction at $260 \mathrm{~nm}$. DNA was extracted by the method of Klemperer (1963) and estimated by the diphenylamine reaction of Burton (1956). Tetrahydrofolate dehydrogenase activity was determined using the method of Perkins, Hillcoat \& Bertinol (1967). The results were statistically analysed using Student's $t$ test (Bruning \& Kintz, 1968).

\section{RESULTS}

Table 2 shows the composition of the foetuses and placentas from rats given diets without folic acid (group A) or with folic acid $(0.0018 \mathrm{~g} / \mathrm{kg}$, group B; $0.0018 \mathrm{~g} / \mathrm{kg}+\mathrm{I} \mathrm{mg} / \mathrm{rat}$ per d, group $\mathrm{C}$ ) during pregnancy. Groups $\mathrm{B}$ and $\mathrm{C}$ had significantly heavier foetuses than group A by 12 and $32 \%$ respectively. There were also significant increases in DNA, RNA and protein content associated with the feeding of dietary folate. In every parameter measured the values for the supplemented group (group C) were also significantly greater than those for group B.

Similar differences were found for the placentas. Again those of groups B and C were heavier than those of Group A, and contained correspondingly more RNA, DNA and protein. Furthermore, the values attained for group $\mathrm{C}$ were higher than those for group $\mathrm{B}$.

With regard to the results for foetal tetrahydrofolate dehydrogenase activity, expressed/ $\mathrm{mg}$ protein, values for groups $\mathrm{B}$ and $\mathrm{C}$ were 25 and $72 \%$ greater respectively than those for group A. Expressed on a whole foetus basis these differences become even greater, namely $37 \%$ for group B and $178 \%$ for group C. 


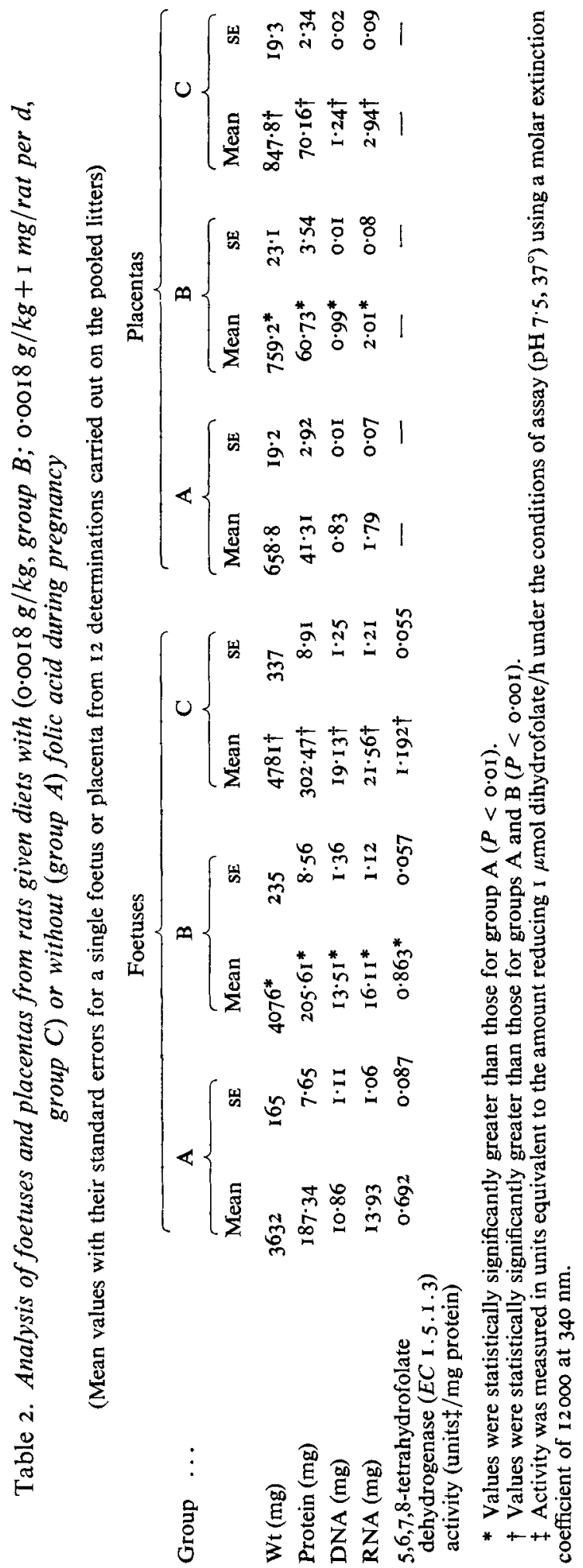


Table 3. Analysis of maternal livers at 2I $d$ of gestation in rats given diets with $(0.0018 \mathrm{~g} / \mathrm{kg}$, group $B ; 0.0018 \mathrm{k} / \mathrm{kg}+\mathrm{I} \mathrm{mg} / \mathrm{rat}$ per day, group $C$ ) or without (group A) folic acid during pregnancy

(Mean values with their standard errors for 12 rats/group)

\begin{tabular}{|c|c|c|c|c|c|c|}
\hline Group ... & $A$ & & B & & $\mathrm{C}$ & \\
\hline & Mean & SE & Mean & SE & Mean & SE \\
\hline Wt (g) & I $4 \cdot 3 \mathrm{I}$ & $I \cdot 19$ & $15.27^{*}$ & 1.07 & $17.95 \dagger$ & $I \cdot I I$ \\
\hline Protein $(\mathrm{g})$ & $2 \cdot I I$ & 0.05 & $2.93^{*}$ & 0.10 & $3.27 t$ & 0.09 \\
\hline DNA (mg) & $3 I \cdot 7 I$ & 2.05 & $36 \cdot 73^{*}$ & $I \cdot 75$ & $42 \cdot 13 t$ & $2 \cdot 36$ \\
\hline RNA (mg) & $166 \cdot 52$ & $7 \cdot 31$ & $215^{\circ} 17^{*}$ & $10 \cdot 10$ & $241.87 \dagger$ & $9 \cdot \mathrm{II}$ \\
\hline $\begin{array}{l}\text { Tetrahydrofolate } \\
\text { dehydrogenase (EC } 1.5 \cdot 1 \cdot 3) \\
\text { activity (units } \ddagger \text { mg protein) }\end{array}$ & 0.479 & 0.059 & $0.585^{*}$ & 0.041 & $0.8 \mathrm{I} 5 \dagger$ & 0.074 \\
\hline
\end{tabular}

Table 3 shows the results of analyses carried out on the maternal livers at 21 days of gestation. The livers of pregnant rats in both groups $B$ and $C$ show significant increases over values for group A in all parameters measured. Once more the extent of the increase was determined by the amount of folic acid the rats were receiving with rats in group $\mathrm{C}$ showing higher values than either of the other two groups.

The hepatic tetrahydrofolate dehydrogenase results are similar to those for the foetuses already discussed. In the table the activities per gram are 22 and $70 \%$ greater in groups $B$ and $C$ respectively than in group $A$ but calculated per whole liver these differences rise to $70 \%$ for group B and $164 \%$ for group C.

\section{DISCUSSION}

Due to the synthesis of folic acid by its intestinal flora, a rat has no dietary requirement for folic acid under conventional conditions. However, as the rats were housed on grids their opportunities for coprophagy were limited. Thus, the folic acid intake of group A was minimal. The level of folic acid in the diet of the other two groups $(1.8 \mathrm{mg} / \mathrm{kg})$ is of the same order as believed by the American Institute of Nutrition (1977) to be several times the rat's requirement. This means that group $B$ was getting more than its requirement and group $\mathrm{C}$ many times that figure.

As all rats in the study received the same amounts of energy, protein, and all other nutrients except folic acid, the results clearly show that there was a relationship between the amount of folate in the diet and the growth of the products of conception. When the dietary folate was raised from zero to $1.8 \mathrm{mg} / \mathrm{kg}$ we observed a marked increase in growth of foetuses, placentas and livers, which was more than doubled when an additional I $\mathrm{mg}$ folic acid/rat per d was given parenterally.

In addition to any direct effects that folate may have had, the increased growth, and consequent expanded surface area exhibited by the placentas from the folate-supplemented rats could have contributed to the higher foetal weight by facilitating nutrient transfer.

Several workers have shown that livers of pregnant rats show a progressive increase in weight, RNA, DNA and protein during gestation (Morgan \& Winick, 1977; Campbell, Fell \& Mackie, 1974; Naismith, 1966). However, the present study has demonstrated that 
the feeding of excess folate to rats during pregnancy is associated with an additional increment in hepatic growth. The increased cellularity brought about by pregnancy may have evolved to make provision for a larger functional liver able to cope with the tremendous metabolic load imposed on small animals at this time. If the additional hepatic tissue produced by folate supplementation were metabolically active it would make a further important contribution to the metabolic adaptations to pregnancy in the rat. In larger animals, by comparison, pregnancy is not instrumental in effecting histological changes in the liver and imposes a relatively small metabolic load (Blaxter, 1964).

The results presented here indicated that tetrahydrofolate dehydrogenase levels were very sensitive to the level of folate intake in that they were depressed when it was low and enhanced greatly when it was high. This increased activity could account for the increment in the rate of DNA and RNA synthesis characteristic of the tissues from the supplemented rats, by promoting purine and pyrimidine biosynthesis. Thus, Brade, Jarck \& Velter (I 972) found that a single injection of $\mathrm{I} \cdot 13 \mathrm{mM}$-folic acid/ $\mathrm{kg}$ body-weight caused an increased RNA production and an increase in the protein content of rat kidney. Although part of the increased activity of tetrahydrofolate dehydrogenase shown here is probably enzyme induction by excess folate acting to facilitate its own degradation much of it is possibly due to the folate indirectly promoting new enzyme protein synthesis by its general facilitation of synthesis of DNA, RNA and protein.

The importance of folic acid in reproductive performance is controversial but it does seem likely that beneficial effects on foetal growth from folate supplements will be seen in any population where marginal dietary folate intakes prevail. A study conducted by Baumslag, Edelstein \& Metz (1970) on an African population deficient in folic acid supports this idea. They were able to show that folate supplements given to women during pregnancy had a beneficial effect on birth-weights. The present results demonstrated that such supplementation will have a similar effect in the rat. Moreover, they also demonstrate that maternal liver growth and the activity of tetrahydrofolate dehydrogenase in both the maternal liver and foetal tissue is increased with folate supplementation during pregnancy, which could provide the underlying mechanism for the enhanced growth.

\section{REFERENCES}

American Institute of Nutrition (1977). J. Nutr. 197, 1340.

Baumslag, N., Edelstein, T. \& Metz, T. (1970). Br. med. J. I, 16.

Bernhart, F. \& Tomarelli, R. (1966). J. Nutr. 89, 495.

Blaxter, K. L. (1964). In Mammalian Protein Metabolism, vol, I1, p. I72 [H. N. Munro and J. B. Alison, editors]. New York: Academic Press.

Brade, W., Jarck, A. \& Velter, J. (1972). Biochem. Pharmac. 2r, I43I.

Bruning, J. L. \& Kintz, B. L. (1968). In Computational Handbook of Statistics, p. 9. Illinois: Foresman and Company.

Burton, K. (1956). Biochem. J. 62, 315.

Campbell, R. M., Fell, B. F. \& Mackie, W. S. (1974). J. Physiol. 24I, 699.

Iyengar, L. \& Apte, S. U. (1972). Br. J. Nutr. 27, 313.

Iyengar, L. \& Rajalakshmi, L. (1975). Am. J. Obstet. Gynec. 122, 332.

Klemperer, G. (1963). Meth. biochem. Analysis r, 287.

Lowry, O. H., Rosebrough, N. J., Farr, A. L. \& Randall, R. J. (1951). J. biol. Chem. 193, 265.

Morgan, B. L. G. \& Naismith, D. J. (1977). J. Nutr. 107, 1590.

Morgan, B. L. G. \& Winick, M. (1977). J. Nutr. 107, I694.

Munro, H. N. \& Fleck, A. (1966). Meth. biochem. Analysis 14, 113.

Naismith, D. J. (1966). Metabolism 15, 1582.

Naismith, D. J. \& Morgan, B. L. G. (1976). Br. J. Nutr. 36, 563.

Nelson, M. M. \& Evans, H. M. (I953).J. Nutr. 51, 7 I.

Perkins, J. P., Hillcoat, B. L. \& Bertinol, J. R. (I967). J. biol. Chem.. 242, 477 I.

Winick, M. (1968). In Diagnosis and Treatment of Foetal Disorders, p. 95 [K. Adamsons, editor]. Basel and New York: Springer-Verlag.

Zeman, F. J. \& Stanbrough, E. C. (1969). J. Nutr. 4r, 274. 